\title{
Assessment the Potential Impacts of Urbanization: Case of Jimma City
}

\author{
W. Takala Dibaba*, M. Kebede Leta \\ Faculty of Civil and Environmental Engineering, Jimma Institute of Technology, Jimma University, Jimma, Ethiopia
}

\section{PAPER INFO}

\section{Paper history:}

Received 03 June 2019

Accepted in revised form 16 September 2019

\section{Keywords:}

Ecosystem

Jimma City

Urbanization

Water Quantity and Quality

\section{$A B S T R A C T$}

Currently the effect of urban discharges on water quantity and quality issues and additional recreational amenities perceived in the urban landscape have gained growing public interest for the provision of sustainable urban development. This is due to the fact that urbanization is converging to challenge city infrastructure due to their adverse impacts on precipitation extremes and the environment of urban areas at large. This study was aimed at identification of the treats of urban expansion and prediction of the environmental responses to urbanization of Jimma City. This is an important input for the decision of environmentalists, hydrologists, storm and waste water management for the better plan and sustainable development of the city. The study analysis of stream flow indicates, urbanization was found to be one of the responsible factors for changing the surface of the land disturbing the hydrological process of Jimma City by altering the magnitude of surface runoff, aquifer recharge and river flows. The expansion of Jimma city have intensified, surface water discharges from developed areas and uncontrolled waste release which have affected the social, environmental and economic state of the area. Increased flood peaks, water volume and pollutant loads, reduced ground water recharge were found to be the major sources water quantity and quality degradation. Degraded water quantity and quality in turn resulted in water crisis, ecological risk, reduced quality of life and reduced level of ecosystem service.

doi: $10.5829 /$ ijee.2019.10.03.06

\section{INTRODUCTION}

Urbanization is one of the challenging city drainage infrastructures due to the hostile impacts of precipitation extremes and the environments of urban areas [1]. Increasing urbanization therefore refers intensifications in extent and density of urban areas [2]. Urban development alters physical characteristics of watershed through changing the terrain, modifying the vegetation and soil characteristics through the development of urban infrastructure. As cities expand and lifestyle is changed, there would be an increasing storm runoff responses to precipitation due to greater storm water peaks generated by impervious surfaces and waste disposal [3, 4]. Similarly, urban land use can also influence timing and magnitude of precipitation inputs to urban watersheds. Limited capacity of drainage system to cope the extreme rainfalls and floods are expected to occur when the system gets overloaded [5]. An increase in impervious pavements and buildings are the causes associated with the hydrologic and morphological impacts.

Impacts due to urbanization could entail a substantial increase in the frequency and magnitude of urban flooding in many regions of the world. With a rapid expansion of infrastructures, the results can be seen in hard surfaces replacing permeable soil, hence not allowing the water to infiltrate and quickly conducting it towards the pipes [6]. The problems associated with urban drainage system can be associated with urban runoff quantity and quality, landscape aesthetics, ecology and beneficial uses and with the operation of existing urban wastewater systems [7]. In this regard, need to embrace the important aspects of urban water management, runoff quantity and quality, ecosystem service and ecological protections should become a forefront issues in urban areas.

Research and experience continually confirm that besides environmental concerns, there also has been increasing criticism on the limited capacity and flexibility of conventional sewer systems to adapt to future climatic variability and urbanization [1]. This requires a new paradigm for urban drainages to take into account all parts of the urban water cycle in management to ensure economic, social, ecological and environmental sustainability [8]. At the same time, water quality problems also emerge as a result of urbanization that 
increases the variety and amount of pollutants and nutrients in receiving water bodies [9]. Even though pollutions arising from urban runoff may be is unavoidable, sustainable drainage systems can significantly reduce harm to water resources and improve the quality of built environments.

Along with the urban developments of Jimma City, the river banks of Awetu that cross the city from north to south are encroached by settlements. Residents of these settlements dispose both solid and liquid waste to the river, due to which it is currently polluted. The pollution of this river contaminates farming areas in the south affecting large number of peasant families. All major and big institutions including Jimma University are also disposing their untreated waste directly to streams. The progressive deterioration of water quality not only inflicts water borne diseases among the people but also aggravates water scarcity and disrupts aquatic biodiversity. The study conducted by Dibaba [10] on the sustainability of Jimma urban drainage system found that uncontrolled waste disposal, poor drainage performance and rapid expansion of the city were the major challenges of Jimma city.

Thus, great deal of attention has to be paid to the question of sustaining the urban ecosystem and environment i.e. how to ensure, systems will continue to function under a growing urbanization and climate change and how to improve and attain sustained developments of Jimma City. This study has identified the major challenges of Jimma City Urbanization and the effect of urbanization on water quantity and quality was addressed.

\section{MATERIALS AND METHODOLOGY}

\section{Study area}

The study area, Jimma Town is located at $352 \mathrm{~km}$ away from Addis Ababa in south-western direction. It is located between $7.40^{\circ}$ north latitude and $36.50^{\circ}$ east longitude. It is situated at the center and is accessible to all parts of the south western part in all direction. The map of the study area is shown in Figure 1.

\section{Methodology}

The descriptive type of research was used to describe the existing condition and coverage of urban infrastructure and their problems. Whereas, the exploratory type was used particularly to explore the existing condition of urbanization of Jimma City which were not found in the base-map.

The approaches and methodologies which were followed to meet the specified objectives of this study are through desk study, field observation and mapping and analysis. Field observation and interviews, hydrological data, satellite images and governmental records were used to develop the basic data set of the study.

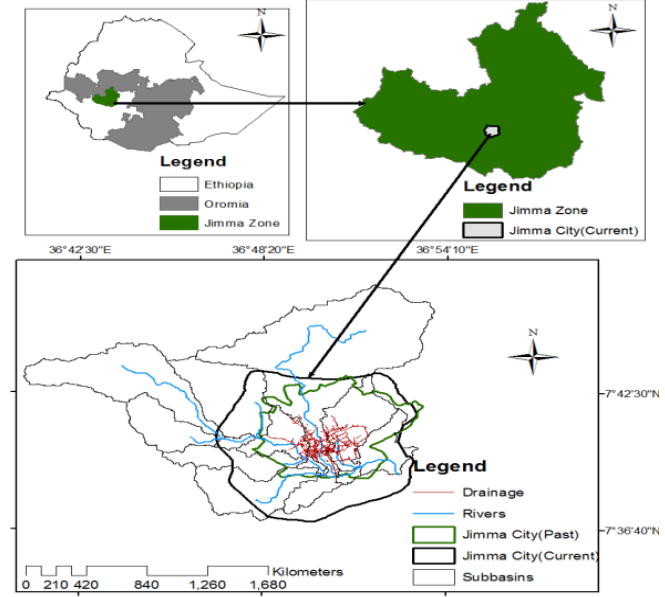

Figure 1. Map of the study area

Field observations and interviews are used to take traverse to different areas for observations and mapping, identify the factors and collect data from concerned secteral offices.

Also, Review of previous master plan reports and maps, and other previous works relevant for the study such as reports, maps, DEM, top maps, collecting satellite datas (land sat data's) are used.

\section{RESULT AND DISCUSSIONS}

\section{Major problems of urbanization on Jimma City}

The conversion of the earth's land surface to urban uses hastens the loss of productive farm lands, changes climate and modifies hydrological process and physical characteristics of the catchment. Consequently, ecosystem of Jimma city has been disturbed due to over exploration of the nature through deforestation and vegetation clearing, housing expansion, climate change, landscape and stream network change, pressure on water resources and unplanned urban expansion. The pressure on land and water resources to meet the increasing demands generated due to basic needs of the community, industrial and small scale enterprises, institutions have accelerated the rate of erosion and flooding, water scarcity, ecological risk and reduced ecosystem service. The study also indicates that increased sediment loading, loss of riparian ecosystem, changes in river morphology, decline in base flow and increased frequency of flooding were the annexes of Jimma urbanization.

The rapid growth experienced over the decade had almost consumed the available open area to the maximum and the city had begun to ponder on how to respond to the needs in the future. Moreover, failures to give recognition to environmental constraints, socio economic and socio cultural situations and deficiency in addressing population growth potential are the major problems of Jimma city development (Figure 2). 


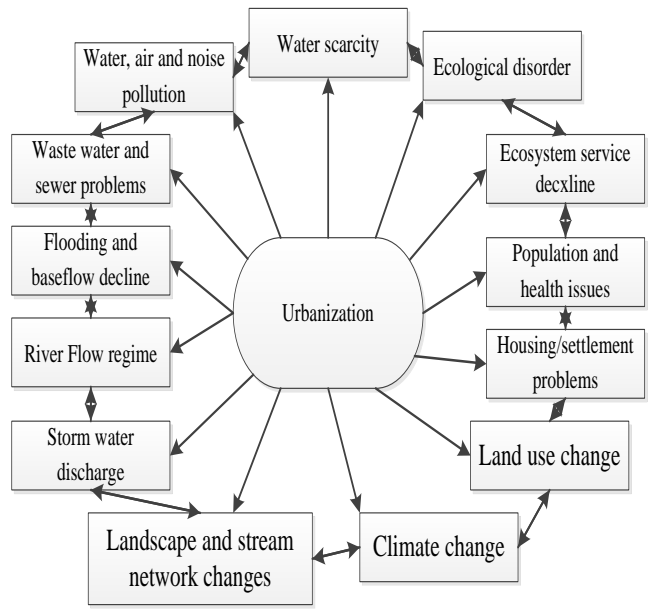

Figure 2. Major problems of urbanization in Jimma city

Experts from Jimma city municipality and professional residents of the city were involved in conducting survey on the major challenges of urbanization in Jimma city. Finally, the respondents' prioritization results are summarized in Table 1.

\section{Urbanization impacts on water quantity and quality}

Normal rainfalls are expected to totally infiltrated or absorbed in to the ground with some proportions forming overland flows to join water courses. However, the development of urban, rural residential, commercials and built environment with impervious surfaces in Jimma city changed the absorption of water into the ground. Consequently, increased flood peaks, water volume and pollutant loads, reduced the ground water recharge was the major sources for quantity and quality of water degradation. In fact quantity and quality of water depends on geology, terrain, land use and degree of imperviousness. Degraded water quantity and quality in turn results in water crisis, ecological risk, reduces quality of life and reduce the level of ecosystem service.

TABLE 1. Respondents prioritizations

\begin{tabular}{lcccccc}
$\begin{array}{l}\text { Challenges of } \\
\text { urbanization in } \\
\text { Jimma city }\end{array}$ & \multicolumn{1}{c}{ Prioritizations of the problems in percentage } \\
\hline & 1st & 2nd & 3rd & 4th & 5th & 6th \\
\hline Flooding & 25 & 12.5 & 37.5 & 25 & 0 & 0 \\
Drainage & 37.5 & 37.5 & 25 & 0 & 0 & 0 \\
water supply & 0 & 12.5 & 0 & 50 & 12.5 & 25 \\
access road & 0 & 0 & 0 & 0 & 50 & 50 \\
waste management & 37.5 & 25 & 25 & 12.5 & 0 & 0 \\
$\begin{array}{l}\text { road drainage } \\
\text { integration }\end{array}$ & 0 & 12.5 & 12.5 & 12.5 & 37.5 & 25 \\
\hline & & & & & &
\end{tabular}

Figure 3 shows the effect of Urbanization on water quantity and quality.

The effect of urbanization of Jimma city on surface water is easily visible as shown in the flow hydrographs (Figure 4). The analysis was done on the annual bases. The graph reveals that Awetu River flow before 1999 is high and from 2000 onwards the flow of the river is very low. In addition there are evidences showing that before 1999 the river has been used for recreation, fishery and tourism. However, from 2000 up to now because of the flow decline, the recreation center along the river bank is closed and there is no fishery activity on the river. Furthermore, the smell of the river currently is very bad and the river is almost like an open sewer.

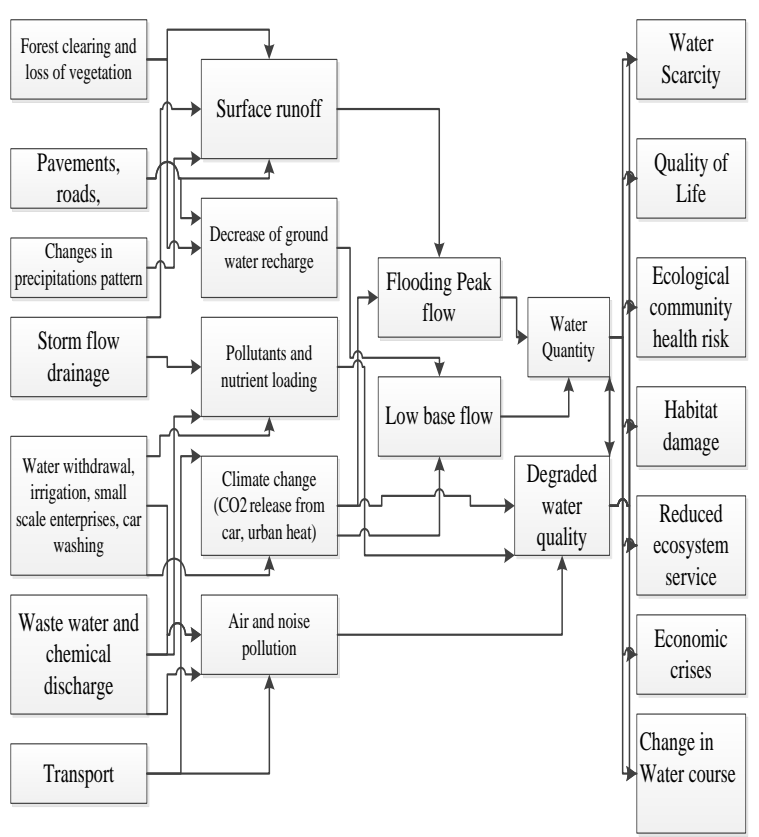

Figure 3. Flow chart showing how urbanization affects water quantity and quality

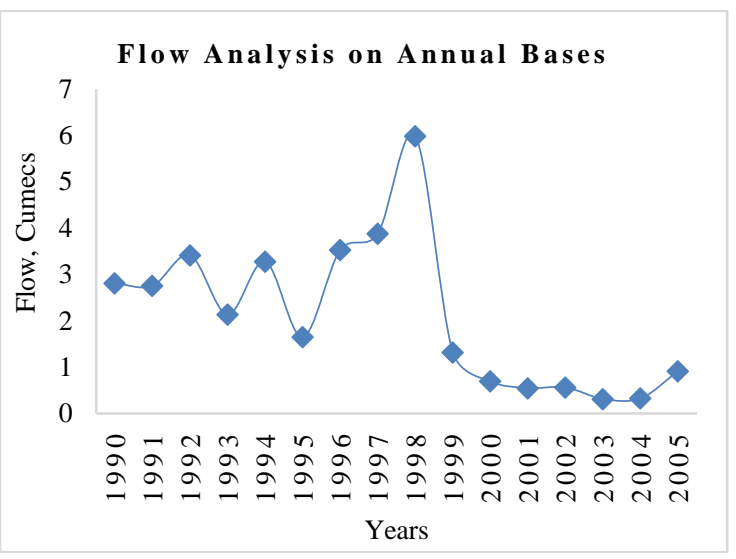

Figure 4. Awetu Flow Analysis 


\section{CONCLUSION}

Unplanned house developments, small scale enterprises, infrastructure developments in Jimma city and environmental challenges were the major problems of urbanization. The drainage network, water supply and sanitation issues were less attended irrespective of the relative strong felt need. Buildings and uncontrolled activities along the river made the community more vulnerable to flooding. Therefore, development along the river must incorporate strategies to maintain and restore natural vegetation as a buffer along the water edge.

During the study survey, information gap and lack of proper communication with relevant bodies were observed. So, to insure sustainable development of Jimma city, Media and civil society, city municipalities and community participation and involvement have to be assured. Need for an integrated urban developments, Need for social infrastructure and public services are alsohighly imperious.

\section{ACKNOWLEDGEMENT}

We would like to thank Jimma University, Jimma Institute of Technology for funding the research. We would also thank Jimma City Municipality, and all individuals for their consent to get information and data.

\section{REFERENCES}

1. Zhou, Q., 2014, A review of sustainable urban drainage systems considering the climate change and urbanization impacts, Water, 6(4), pp.976-992.

2. Singh, P., Kikon, N. and Verma, P., 2017, Impact of land use change and urbanization on urban heat island in Lucknow city, Central India. A remote sensing based estimate, Sustainable Cities and Society, 32, pp.100-114.

3. Grimm, A., 2007, The extent to which sustainable urban drainage systems (SUDS) are considered in environmental impact assessment (EIA), M.Sc.Thesis, University of East Anglia.

4. O'Driscoll, M., Clinton, S., Jefferson, A., Manda, A. and McMillan, S., 2010, Urbanization effects on watershed hydrology and in-stream processes in the southern United States, Water, 2(3), pp.605-648.

5. Zhou, Q., Arnbjerg-Nielsen, K., Mikkelsen, P.S., Nielsen, S.B. and Halsnæs, K., 2012, Urban drainage design and climate change adaptation decision making, PhD. Thesis, DTU Environment.

6. Belete, D.A., 2011, Road and urban storm water drainage network integration in Addis Ababa: Addis Ketema Sub-city, Journal of Engineering and Technology Research, 3(7), pp.217-225.

7. Chocat, B., Krebs, P., Marsalek, J., Rauch, W. and Schilling, W., 2001, Urban drainage redefined: from stormwater removal to integrated management, Water Science and Technology, 43(5), pp.61-68.

8. Miguez, M.G., Veról, A.P. and Carneiro, P.R.F., 2012, Sustainable drainage systems: an integrated approach, combining hydraulic engineering design, urban land control and river revitalisation aspects, In Drainage systems, IntechOpen.

9. Hatt, B.E., Fletcher, T.D., Walsh, C.J. and Taylor, S.L., 2004, The influence of urban density and drainage infrastructure on the concentrations and loads of pollutants in small streams, Environmental management, 34(1), pp.112-124.

10. Dibaba, W.T., 2018, A review of sustainability of urban drainage system: traits and consequences, Journal of Sedimentary Environments, 3(3), pp.131-137. 